\title{
Quality control of glulam Shear testing of bondlines
}

\section{Journal Article}

\section{Author(s):}

Steiger, René; Gehri, Ernst; Richter, Klaus

Publication date:

2010

Permanent link:

https://doi.org/10.3929/ethz-b-000157724

\section{Rights / license:}

In Copyright - Non-Commercial Use Permitted

\section{Originally published in:}

European Journal of Wood and Wood Products 68(3), https://doi.org/10.1007/s00107-010-0456-4 


\title{
Quality control of glulam: shear testing of bondlines
}

\author{
René Steiger · Ernst Gehri · Klaus Richter
}

Received: 15 January 2010 / Published online: 11 June 2010

(C) Springer-Verlag 2010

\begin{abstract}
In quality control of glulam, shear testing of bondlines is required. However, in relevant standards the method of applying shear stress to the bondline is only exemplified by a principle schematic. Based on this schematic a considerable variety of test equipments is in use nowadays. Depending on the respective construction of the test equipment as well as on the execution of testing, the resulting stress in the bondline is not pure shear but rather a combination of shear and normal stresses. When the normal stresses are acting as tensile stresses perpendicular to the bondline, the registered shear strength values range considerably below the pure shear stress level, whereas compression stresses perpendicular to the grain lead to an overestimation of the shear strength of the bondline. To overcome this deficiency, a prototype of a modified shear test device was developed, which ensures a clearly defined state of shear loading of the specimens. Based on extensive comparative testing it is shown that by performing compression tests at an oblique angle to the grain of $14^{\circ}$ the above mentioned problems can be avoided.
\end{abstract}

This article is dedicated to Gerd Wegener on the occasion of his retirement as professor at the Technische Universität München.

R. Steiger $(\bowtie) \cdot$ K. Richter

Empa, Swiss Federal Laboratories for Materials Science and

Technology, Wood Laboratory, Ueberlandstrasse 129,

8600 Dübendorf, Switzerland

e-mail: rene.steiger@empa.ch

E. Gehri

ETH Zürich, Im Lindengut 13, 8803 Rüschlikon, Switzerland

\section{Qualitätskontrolle von Brettschichtholz: Scherprüfung von Klebfugen}

Zusammenfassung Im Rahmen der Qualitätskontrolle von Brettschichtholz sind Scherprüfungen an Klebfugen durchzuführen. Die bei der Prüfung anzusetzende Belastungskonfiguration ist in den relevanten Prüfnormen lediglich in Form einer Prinzipskizze festgelegt. Heutzutage wird eine Vielzahl unterschiedlicher Prüfgeräte eingesetzt, welche auf Basis der erwähnten Prinzipskizze entwickelt wurden. Beeinflußt durch die konstruktive Umsetzung der Prinzipskizze und durch die Art der Durchführung der Scherprüfung, entspricht der effektiv in der Scherfuge herrschende Spannungszustand nicht reinem Schub, sondern vielmehr einer Kombination von Scherspannung und Spannungen senkrecht zur Scherfläche. In der Scherfuge gleichzeitig mit den Scherspannungen wirkende Zugspannungen senkrecht zur Fuge bewirken ein merkbares Absinken der im Versuch erzielten Scherfestigkeitswerte, z. T. gar unter die eigentliche Schubfestigkeit des Holzes. Auf die Scherfuge senkrecht einwirkende Druckspannungen demgegenüber können zu einer Überschätzung der Scherfestigkeit der Klebfuge führen. Um diesem Problem zu begegnen, wurde ein Prototyp einer Scherprüfeinrichtung entwickelt, welcher den Prüfkörper einem definierten Scherspannungszustand aussetzt. Basierend auf umfangreichen vergleichenden Prüfungen wird gezeigt, dass durch Druckscherversuche unter einem Kraftzur Faserwinkel von $14^{\circ}$ die oben erwähnten Schwierigkeiten umgangen werden können.

\section{Introduction}

For the determination of shear properties of wood and woodbased materials a wide variety of test methods is proposed: 
block shear tests, torsion of prismatic bars, anticlastic bending, Iosipescu shear test, multipoint bending, off-axis tension or compression and in-plane shear loading (Yoshihara and Matsumoto 2005). Additionally, panel shear tests (CEN 2003; Feldborg 1991), short-span bending of rectangular or notched members (Larsen 1987; Radcliffe and Suddarth 1955) and the Arcan shear test (Arcan et al. 1978) exist. All of these methods aim at achieving a well defined and uniform state of shear stress in a well defined test zone. But as discussed below this has proven to be very difficult (Bodig and Jayne 1993; Coker and Coleman 1935; Radcliffe and Suddarth 1955).

With regard to the quality control of bondlines in practice, common one-sided block shear tests are regarded as the most efficient method since the specimens are simple to fabricate and the test process is easy to carry out (ASTM 2003; CEN 1995; ISO 2006; Kollmann and Côté 1968).

\subsection{Block shear tests of bondlines}

\subsubsection{European standards}

In Europe, the requirements for glued-laminated timber are given in the standard EN 14080 (CEN 2005). The bonding strength of bondlines shall be assessed as a bondline integrity test according to one of the test procedures defined in EN 386 (CEN 2001). EN 386 demands delamination tests according to EN 391 and block shear tests according to EN 392 (CEN 1995) and requests that the shear strength $f_{v, a}$ of each bondline shall be at least $6 \mathrm{~N} / \mathrm{mm}^{2}$. For coniferous wood and poplar lower individual values of shear strength (down to $4 \mathrm{~N} / \mathrm{mm}^{2}$ ) can be regarded as acceptable if the wood failure reaches a certain percentage as given in EN 386.

The block shear test to be carried out according to EN 392 is intended to be used for continuous factory quality control of bondlines. The standard presents a principle schematic for the shearing tool. The shearing force shall be applied self-aligning via a cylindrical bearing so that the specimen is loaded at the end grain with a stress field uniform in width direction and the distance between the bondline and the sheared plane nowhere exceeds $1 \mathrm{~mm}$. The specimens shall be of width $b$ and of thickness $t$ between 40 and $50 \mathrm{~mm}$ each. The loaded surfaces are to be smooth and parallel to each other as well as perpendicular to the grain direction.

The shear strength $f_{v, a}$ is derived from

$$
f_{v, a}=k \frac{F_{u}}{A} \quad \text { with } k=0.78+0.0044 \cdot t
$$

with $A=$ sheared area $=b \cdot t, F_{u}=$ ultimate load and $k$ being a modification factor for test pieces where the thickness in the grain direction of the sheared area is less than $50 \mathrm{~mm}$.

\subsubsection{US standards}

In the United States, glulam producers follow quality control guidelines ANSI/AITC 190.1-2002 (AITC 2002) and ANSI/AITC 200-2004 (AITC 2004). Shear testing of bondlines is regulated by AITC Test T107. Concerning shear block tests, reference is made to the American Standard ASTM D 905-03 (ASTM 2003). The shearing tool to be used shall have a self-aligning seat ensuring uniform lateral distribution of the load. The standard ASTM D 905-03 makes the user aware of the fact that "this test method cannot be assumed to measure the true shear strength of the adhesive bond" because "many factors interfere or bias the measurement including the strength of the wood, the specimen, the shear tool designs themselves and the rate of loading". It is also mentioned, that "stress concentrations at the notches of the specimen tend to lower the measured strength" (Okkonen and River 1989). This is in contrast to the test method according to ASTM D 143 (ASTM Standard 2000) where it is said, that "these effects are self correcting so that the measured strength is close to the true shear strength of wood".

\subsubsection{ISO standards}

Within the ISO standards series, ISO 12578 (ISO 2007) deals with the component performance and the requirements for the production of glulam. The formulations in this standard are quite similar to the European equivalent EN 386. In analogy to the latter, one possibility for controlling bondline integrity and strength is to perform block shear tests. Reference is made to the standard ISO 12579 (ISO 2006), which provides a combination of rules and specimen types taken from EN 392 and ASTM D 905. Concerning the apparatus to be used for the shear tests, the standard provides only a schematic diagram similar to EN 392. In the ISO standard 6238 (ISO 2001) which deals with the derivation of shear strength of wood-to-wood adhesive bonds by compressive loading, one can find an example of a shearing tool being identical to the one of ASTM D 905-03.

\subsubsection{Shortcomings of the block shear test method}

The block shear test method has the advantage of being simple with regard to the preparation of the test specimens, the test equipment needed, the overall procedure and the analysis of the test results. However, there are several shortcomings to be mentioned:

- The test method suffers from a non-uniform shear stress distribution with a stress concentration near the corner as was shown by experimental and theoretical stress analysis (Coker and Coleman 1935; Radcliffe and Suddarth 1955). Hence the derived shear strength using (1) is only nominal. 
Fig. 1 Schematic sketch of three EN 392 type shearing tools used by different test labs and glulam producers

Abb. 1 Schematische

Darstellung von drei EN 392 konformen

Scherprüfeinrichtungen, wie sie und

Brettschichtholzproduzenten eingesetzt werden durch verschiedene Prüflabors
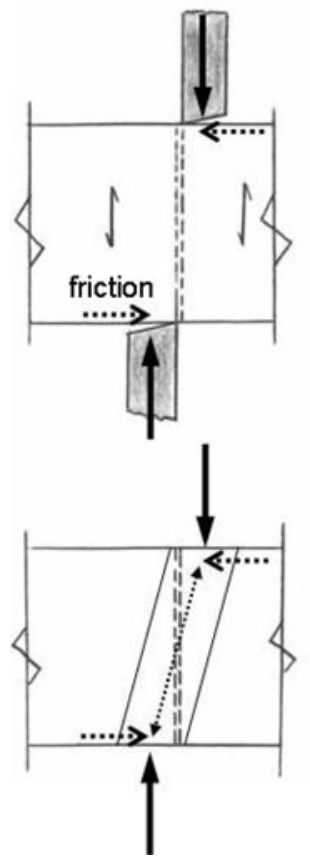

- The test results are influenced by the actual realization of the schematic diagram of EN 392 as well as by the person carrying out the test.

- During the shear test, the specimen is subjected to a shear strain. Most of the existing shearing devices hinder this strain. This results in unknown side effects on the test results.

- Test results derived using different test devices cannot be compared directly. Hence, the method only serves the glulam producer as a kind of warning tool if the test values drop below a certain threshold.

In Fig. 1, as an example, three different types of test devices are shown. It can easily be seen that the fixation and loading of the specimen and thus the resulting stress situation in the bondline are different.

\subsubsection{Analysis of static equilibrium}

The state of static equilibrium in specimens tested according to EN 392 is shown in Fig. 2. Being not aligned but rather eccentric (with a gap $e$ depending on the dimension $\ell_{A}$ of the pistons of the actual test equipment), the acting shearing force $A_{v}$ causes a moment $A_{v} \cdot e$, which is counteracted by the moment $h \cdot A_{h}$. Both the eccentricity $e$ and the counteracting moment are undetermined, since they depend on the actual geometry and construction of the shearing device. Assuming e.g. a mean shear strength of $f_{v, a}=6 \mathrm{~N} / \mathrm{mm}^{2}$ the shear force in a bonded area of $t \times b=45 \times 50 \mathrm{~mm}^{2}$ is $13.5 \mathrm{kN}$ and the equilibrium "frictional force" $A_{h}$ results in $3 \mathrm{kN}$. The "frictional" stress thus is $6 \mathrm{~N} / \mathrm{mm}^{2}$ and the width
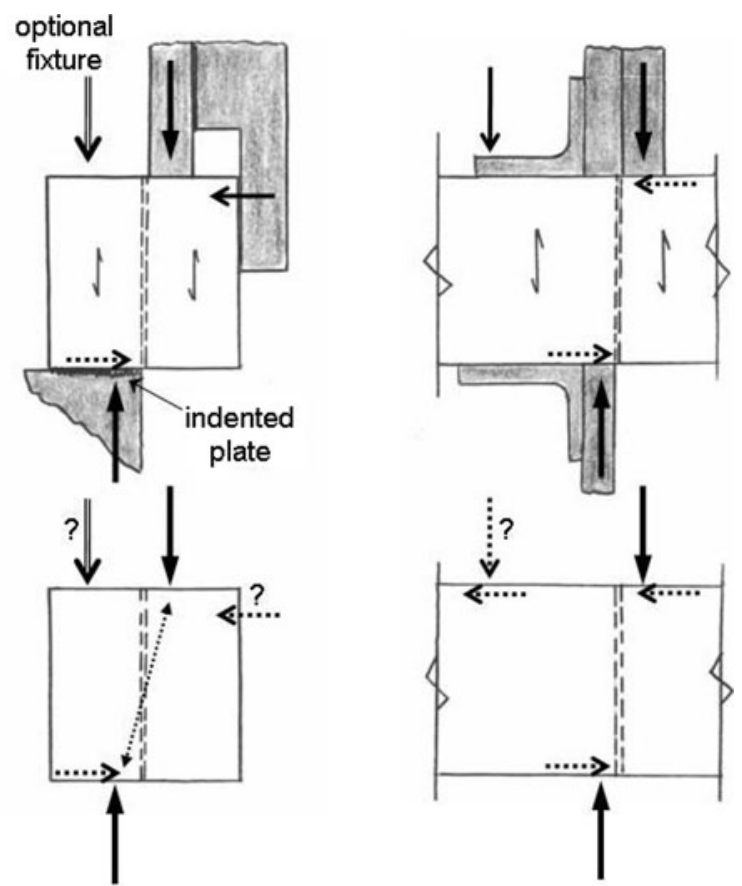

of the punches needs to be 7 to $10 \mathrm{~mm}$, assuming a maximal compression strength parallel to the grain of $f_{c, 0}=30$ to $40 \mathrm{~N} / \mathrm{mm}^{2}$.

Actually there is a state of compression at an angle to the grain $\left(\alpha \approx \arctan \left(A_{h} / A_{v}\right)=\arctan (3 / 13.5)=12.5^{\circ}\right)$ and a counteracting moment is built up when the zone of maximum compression stress is deformed. This deformation leads to an uplift of the test bar. If this uplift is prevented, for example by holding down the test bar, significant bending stresses are added to the acting shear stresses and the specimen tends to fail early at low levels of shear stress.

Simultaneously acting tensile stresses perpendicular to the grain result in lower shear strength whereas compressive forces perpendicular to the grain help to resist higher shear stresses (Karlsen and Goodman 1967).

\subsection{Proposed new method for shear testing of bondlines}

\subsubsection{Approach}

Shear strength can be derived by carrying out compression tests with a certain inclination to the grain. For example, to derive shear strength parallel to the grain EN 408 (CEN 2003) asks for panel shear tests at an oblique angle between the loading direction and the longitudinal axis of the specimen (which is actually the grain direction) of $14^{\circ}$. The procedure to be followed, however, is rather tedious and not suitable for the quality control of bondlines, since tapered steel plates have to be glued to the specimens. But the idea of carrying out a compression test at an oblique angle to the 
Fig. 2 Static equilibrium in specimens tested according to EN 392 (CEN 1995)

Abb. 2 Kräftegleichgewicht bei Scherversuchen gemäß EN 392 (CEN 1995)
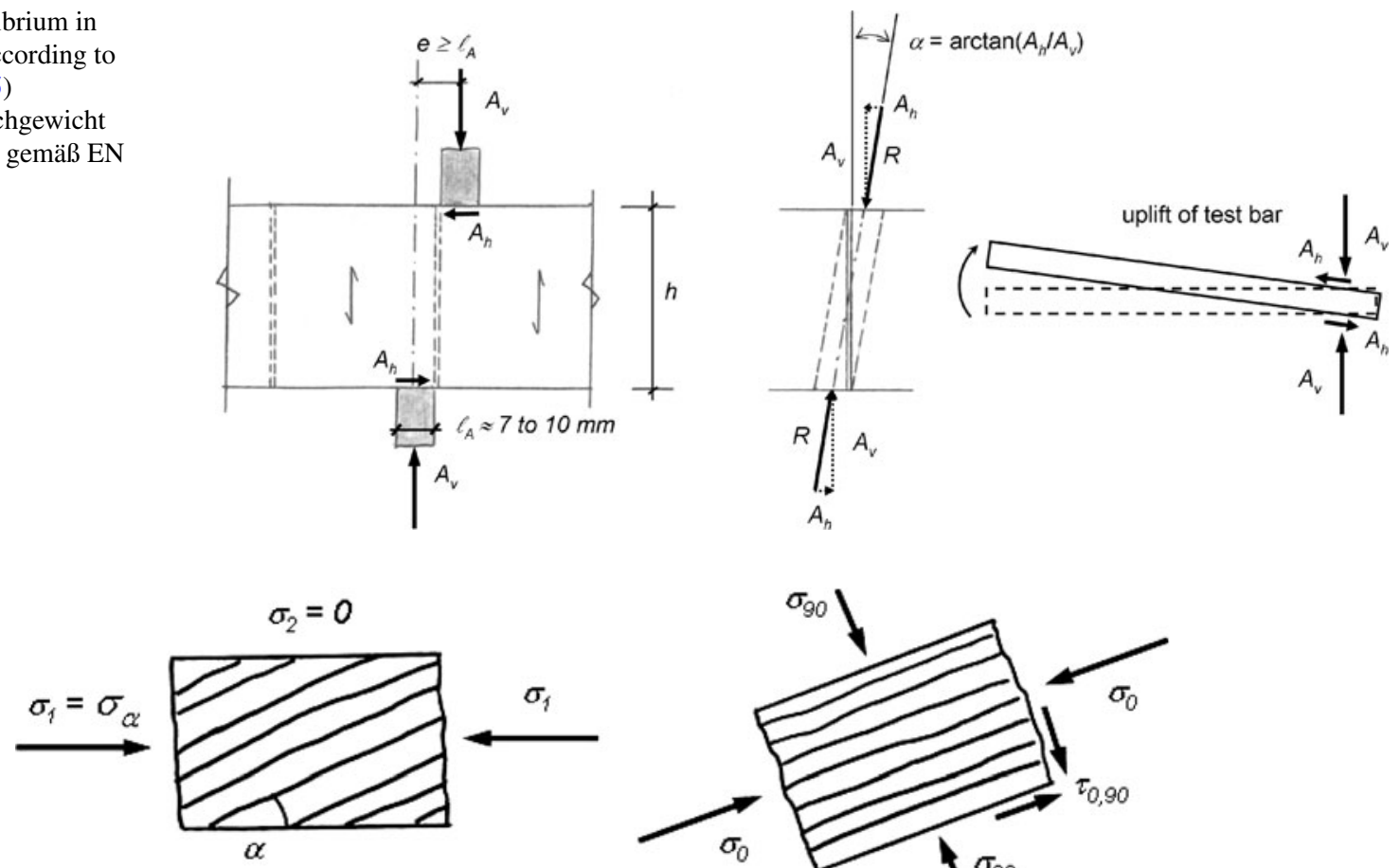

(a)

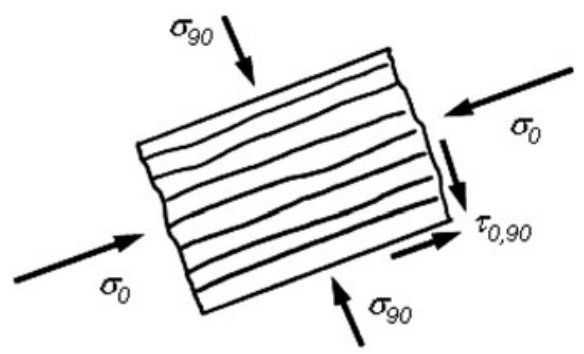

(b)

Fig. 3 (a) 2D-element with a stress $\sigma_{\alpha}$ acting at an angle $\alpha$ to the grain direction. (b) Stresses parallel and perpendicular to grain $\sigma_{0}, \sigma_{90}$ as well as shear stress $\tau$ resulting from $\sigma_{\alpha}$

Abb. 3 (a) 2D-Element mit einer unter einem Winkel $\alpha$ schräg zur Faser wirkenden Normalspannung $\sigma_{\alpha}$. (b) Aus $\sigma_{\alpha}$ resultierende Normalspannungen parallel und senkrecht zur Faser $\sigma_{0}, \sigma_{90}$ und Schubspannung $\tau$

grain can be used to improve the block shear test method as follows:

Different angles $\alpha$ between loading and grain direction can e.g. be modeled using the Hankinson-formula (Hankinson 1921), which was also found independently by Kollmann (1934) based on scientific findings in crystal physics by Hörig (1931). However, the Hankinson-formula does not provide any information on failure modes to be expected with varying angles $\alpha$.

Stüssi $(1946,1949)$ showed (as was already found in 1920 by Jenkin), that for isotropic materials a relation between normal stresses $\sigma$ and shear stresses $\tau$ can be determined by formulating stress equilibrium of a plane strain element subjected to a stress $\sigma_{\alpha}$ inclined by an angle $\alpha$ with reference to the grain direction (Fig. 3a). The principle stresses $\sigma_{1}$ and $\sigma_{2}$ are:

$\sigma_{1}=\sigma_{\alpha}$,

$\sigma_{2}=0$.

Respective stresses parallel and perpendicular to the grain and shear stresses (Fig. 3b) can be calculated according to the theory of the strength of materials:

$\sigma_{0}=\sigma_{\alpha} \cdot \cos ^{2} \alpha$, $\sigma_{90}=\sigma_{\alpha} \cdot \sin ^{2} \alpha$,

$\tau_{0,90}=\sigma_{\alpha} \cdot \cos \alpha \cdot \sin \alpha$.

Depending on the actual angle $\alpha$ between the loading and grain direction there are three different failure modes possible:

- compression failure parallel to the grain:

$$
\sigma_{\alpha}=\frac{\sigma_{0}}{\cos ^{2} \alpha}
$$

- shear failure:

$$
\sigma_{\alpha}=\frac{\tau_{0,90}}{\sin \alpha \cdot \cos \alpha}
$$

- compression failure perpendicular to the grain:

$$
\sigma_{\alpha}=\frac{\sigma_{90}}{\sin ^{2} \alpha}
$$

Solving Airy's stress function, Ylinen (1963) found that these formulas are valid for orthotropic materials as well. The dependency of compression strength from the angle between grain and load direction is shown in Fig. 4, wherefrom it can be concluded that: 
Fig. 4 Influence of the angle between loading and grain direction on compression strength according to Stüssi (1946, 1949)

Abb. 4 Einfluß des Winkels zwischen Kraft- und Faserrichtung auf die Druckfestigkeit nach Stüssi (1946, 1949)

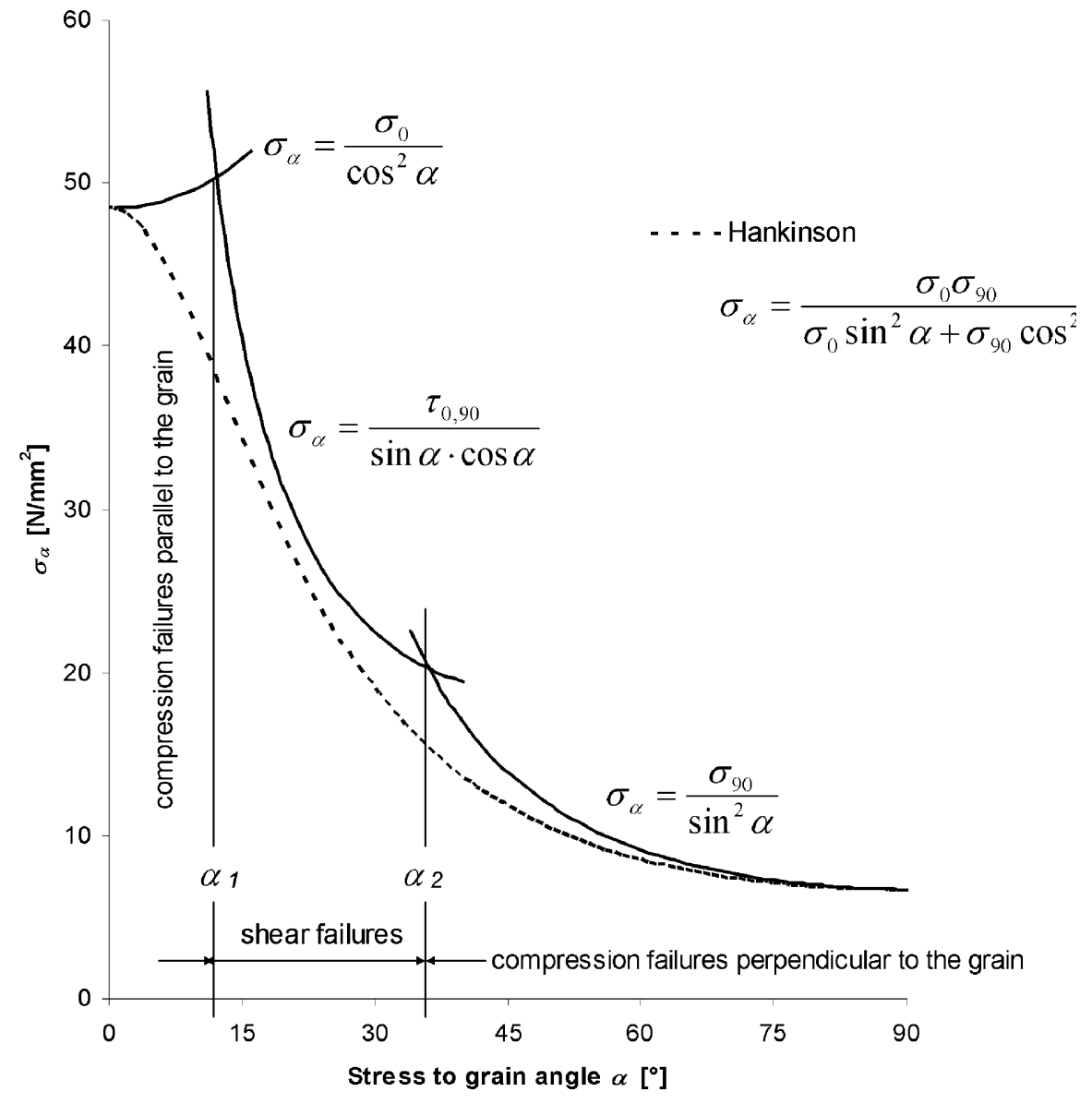

- the shear strength $f_{v, 0,90}$ can be derived from compression tests at an oblique angle $\alpha$ to the grain based on (8):

$f_{v, 0,90}=f_{c, \alpha} \cdot \cos \alpha \cdot \sin \alpha$.

- shear failures can be expected for force to grain angles in the range of $\alpha_{1} \leq \alpha \leq \alpha_{2}$ with $\alpha_{1} \approx 13^{\circ}$ and $\alpha_{2} \approx 34^{\circ}$. Analyzing test results by Baumann (1922) and Kraemer (1929), Stüssi (1945) showed, that this assumption is valid (Gehri and Steurer 1979).

\subsubsection{Prototype of a new shearing tool}

Based on the approach presented above, a prototype of a new test apparatus to derive shear strengths of bondlines has been developed recently (Abplanalp and Bogusch 2007).

Owing to the fact that high compression stresses perpendicular to the grain result in higher shear stresses (Fig. 4), an angle $\alpha$ near $\alpha_{1}$ is to be preferred. In analogy to the EN 408 (CEN 2003) rules for panel shear tests an angle $\alpha$ of $14^{\circ}$ was chosen (Fig. 5), being equal to an inclination of 1:4. Prototype tests and calculations showed that smaller slopes of e.g. 1:5 or 1:6 would not be possible since the specimens crushed due to exceeding compression stresses parallel to

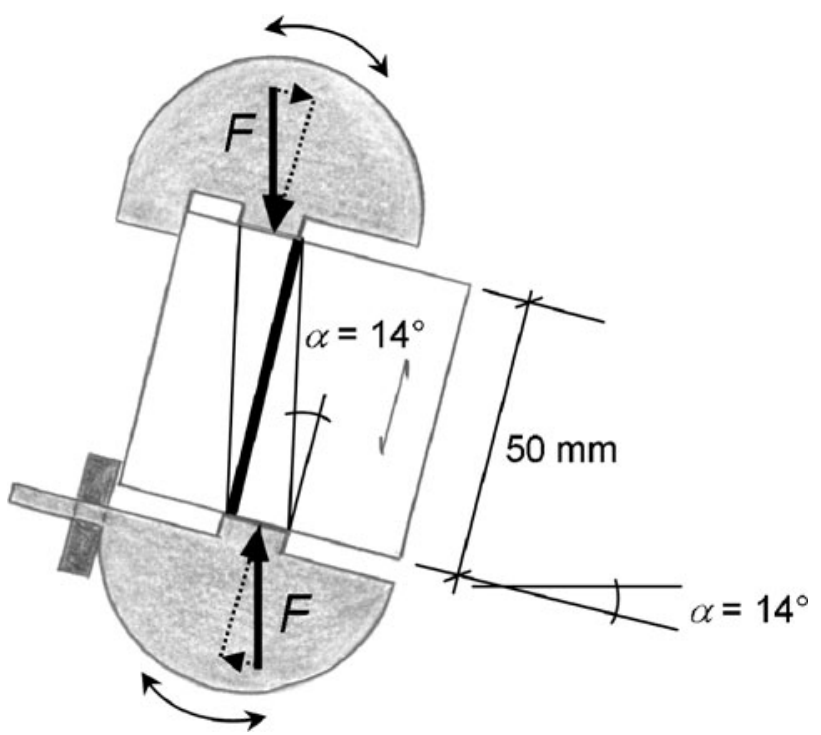

Fig. 5 Loading scheme of the new shearing tool (The arrow in the specimen indicates the grain direction)

Abb. 5 Belastungsschema der neuen Scherprüfeinrichtung (Die Pfeilmarkierung auf dem Prüfkörper zeigt die Faserrichtung an)

the grain in the loading zone. With a slope of 1:4 for softwood specimens, shear strengths up to 10 to $12.5 \mathrm{~N} / \mathrm{mm}^{2}$ 
were recorded resulting in compression stresses parallel to the grain from 40 to $50 \mathrm{~N} / \mathrm{mm}^{2}$.

As is shown in Fig. 6 and was experimentally proven (Keylwerth 1951), a shear strain occurs during the shear test. This strain may not be hindered or blocked but rather be made possible. That is why the upper and the lower plungers are coupled to the loading parts by means of pivot bearings. To account for the specifications given by EN 392 (cylindrical bearing) one of the plungers has a two-way pivot bearing.

When calculating the shear strength $f_{v, a}$ from the ultimate load $F_{u}$ and the sheared area $A=b \cdot t$, it has to be taken into account, that there is an inclination between act-

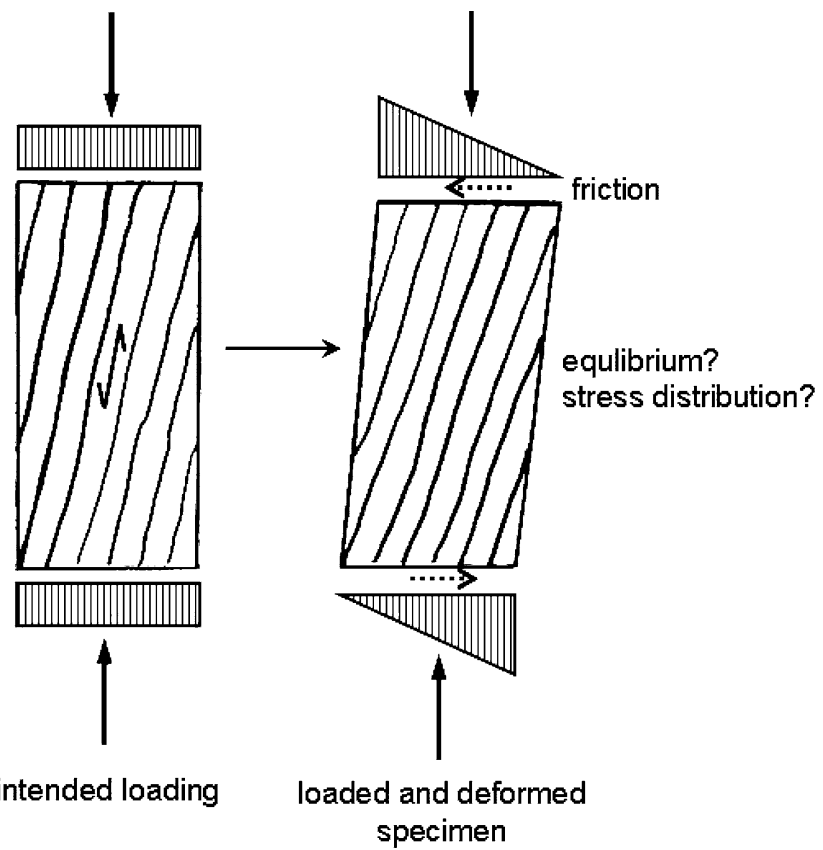

Fig. 6 Intended loading (compression inclined to the grain) (left) and deformed specimen with undefined state of stress and occurring shear strain (friction) in contact with the punches (right)

Abb. 6 Angestrebte Beanspruchung des Prüfkörpers (Druck schräg zur Faser) (links) und verformter Prüfkörper in einem unbestimmten Spannungszustand infolge gleichzeitig mit der Druckspannung wirkender Schubspannung aus Reibung in der Krafteinleitungszone (rechts) ing force and shear plane. The respective formula to derive shear strength therefore is:

$f_{v, a}=\frac{F_{u}}{A} \cdot \cos 14^{\circ}=\frac{F_{u}}{A} \cdot 0.970$.

\section{Experimental}

\subsection{Aims}

The test series carried out aimed at:

- quantifying the influence of friction properties of the plates supporting the specimens when tested with the established device,

- comparing the established device and the prototype of the new device under lab conditions with regard to shear strength and percentage of wood failure for several series of specimens with bondlines made with different types of adhesives,

- evaluating the new shear testing method in terms of handling the device and preparation of test specimens.

\subsection{Method}

\subsubsection{Preliminary test series}

In a preliminary test series, the influence of different friction properties of the steel plates supporting the test bars when performing shear tests with the established device was studied by comparing (a) the situation "indented steel plate" with (b) a plain steel support and with (c) a nearly frictionless situation where a Teflon ${ }^{\circledR}$ sheet was placed between the test bar and the plain steel plate.

In order to prevent test results from being influenced by the type of adhesive, the preliminary test series was carried out on solid wood shear test specimens without any bondlines. The sample size for each type of support $(a, b, c)$ was $n=30$. Each sample was divided into two equally-sized sets of specimens with distinct (low/high) densities (Table 1).
Table 1 Density and moisture content of the test specimens tested in the course of the preliminary test series

Tab. 1 Rohdichte und Feuchtegehalt der Prüfkörper der Vorversuchsreihe

aoven-dry density

${ }^{b}$ spot checks by oven-drying selected specimens

${ }^{c}$ coefficient of variation

\begin{tabular}{|c|c|c|c|c|c|c|}
\hline \multirow[t]{2}{*}{ Subseries } & & \multirow{2}{*}{$\begin{array}{l}\text { Sample } \\
\text { size }\end{array}$} & \multicolumn{2}{|c|}{$\mathrm{MC}[\%]^{\mathrm{b}}$} & \multicolumn{2}{|c|}{ Density $\left[\mathrm{kg} / \mathrm{m}^{3}\right]^{\mathrm{a}}$} \\
\hline & & & Mean & Range & Mean & $\mathrm{CoV}^{\mathrm{c}}$ \\
\hline \multirow[t]{2}{*}{ Indented plate } & High density & 15 & \multirow{6}{*}{11.3} & \multirow{6}{*}{$10.4-12.2$} & 442 & $1.23 \%$ \\
\hline & Low density & 15 & & & 362 & $1.44 \%$ \\
\hline \multirow[t]{2}{*}{ Plain plate } & High density & 15 & & & 444 & $2.10 \%$ \\
\hline & Low density & 15 & & & 362 & $1.57 \%$ \\
\hline \multirow[t]{2}{*}{ Teflon ${ }^{\circledR}$ sheet } & High density & 15 & & & 442 & $1.96 \%$ \\
\hline & Low density & 15 & & & 363 & $1.73 \%$ \\
\hline
\end{tabular}




\subsubsection{Main test series}

The main test series concentrated on comparing shear strengths and percentages of wood failure derived from tests with either the established device or the new one. Comparability of test results was made possible by testing pairs of edge bars (E) and centre bars (C) taken from two slices (A and B) cut from front ends of glulam beams directly after finishing the production in the glulam plant (Fig. 7). Eight glulam producers supplied the test bars cut from 3 to 4 different glulam beams each. The bars contained 8 to 10 bondlines. Due to geometrical restrictions when trimming the block shear specimens, not all bondlines could be tested. The actual sample sizes are reported in Table 2. In total approximately 600 block shear tests were carried out in the course of the main test series.

\subsubsection{Test procedure}

The block shear specimens were tested to shear failure using either the established shear test device (with indented steel plate as support) or the new one. Force was applied
Fig. 7 Sampling of test bars for the main test series: Two slices $A$ and $B$ containing pairs of edge bars (E) and centre bars (C) of cross-section $50 \times 50 \mathrm{~mm}^{2}$ were cut from front ends of glulam beams Abb. 7 Probenahme für die Hauptversuchsreihe: Zwei Scheiben A und B, enthaltend Paare von Prüfstangen mit den Querschnittsabmessungen $50 \times 50 \mathrm{~mm}^{2}$, entnommen vom Rand des

Brettschichtholzträgers (E) und aus dessen Mitte (C)

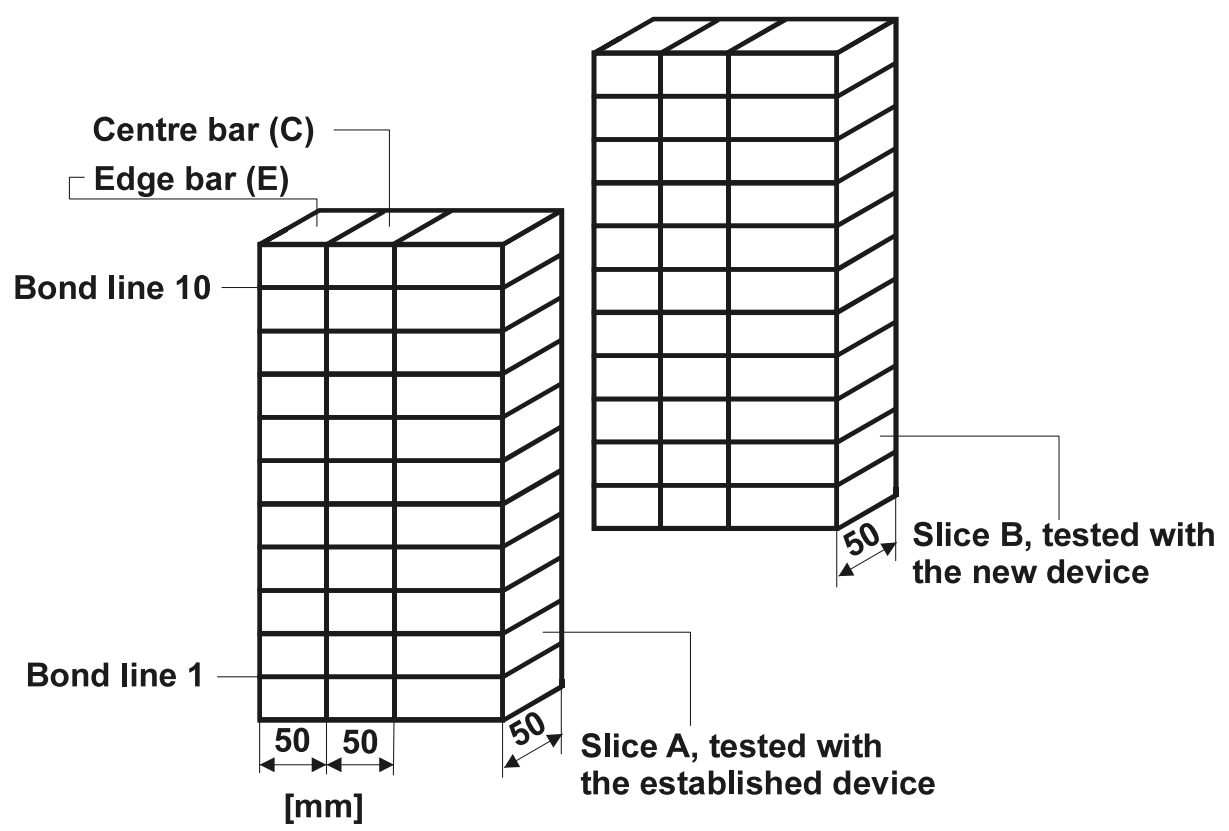

Table 2 Properties of test specimens tested in the course of the main test series

Tab. 2 Eigenschaften der Prüfkörper der Hauptversuchsreihe

\begin{tabular}{|c|c|c|c|c|c|c|}
\hline \multirow[t]{2}{*}{ Glulam producer } & \multirow[t]{2}{*}{ Adhesive $^{\mathrm{a}}$} & \multicolumn{2}{|c|}{ Established device } & \multicolumn{2}{|l|}{ New device } & \multirow[t]{2}{*}{ Glulam class } \\
\hline & & Sample size & $\mathrm{MC}[\%]^{\mathrm{b}}$ & Sample size ${ }^{c}$ & $\mathrm{MC}[\%]^{\mathrm{b}}$ & \\
\hline \multirow[t]{2}{*}{ A } & $\mathrm{RF}$ & 21 & \multirow{9}{*}{$\begin{array}{l}11.5 \\
(0.045)\end{array}$} & $17(4)$ & \multirow{9}{*}{$\begin{array}{l}12.3 \\
(0.034)\end{array}$} & \multirow{5}{*}{ GL 24h } \\
\hline & UF & 18 & & 18 & & \\
\hline $\mathrm{B}$ & PUR & 40 & & $26(14)$ & & \\
\hline $\mathrm{C}$ & MUF & 65 & & $54(11)$ & & \\
\hline $\mathrm{D}$ & PUR & 38 & & $22(16)$ & & \\
\hline $\mathrm{E}$ & PUR & 21 & & $18(1)$ & & unknown \\
\hline $\mathrm{F}$ & MUF & 40 & & $37(3)$ & & GL 24h \\
\hline $\mathrm{G}$ & MUF & 42 & & 42 & & GL 24c \\
\hline $\mathrm{H}$ & EPI & 40 & & $36(4)$ & & GL 24h \\
\hline
\end{tabular}

${ }^{a} \mathrm{PUR}=$ Polyurethane, MUF $=$ Melamine-Urea-Formaldehyde, $\mathrm{RF}=$ Resorcinol-Formaldehyde, UF $=$ Urea-Formaldehyde, EPI $=$ Emulsion Polymer Isocyanate

${ }^{\mathrm{b}} \mathrm{MC}=$ moisture content: mean value and (coefficient of variation)

${ }^{c}$ in brackets: number of tests where the ultimate load could not be reached due to insufficient travel of the piston

daccording to EN 14080 (CEN 2005) 
by a $100 \mathrm{kN}$ universal testing machine Zwick with a loading rate of $3 \mathrm{~mm} / \mathrm{min}$. Maximal error of the force measurement was $<1 \%$. Shear strength was calculated by dividing the registered maximum force by the sheared area according to (1) and (11), respectively. Additionally the percentages of wood failure in the bondlines were determined using a new semi-automatic method (Künniger 2008). There, for a better differentiation of wood fibers and adhesive, the fractured surface is stained using an acid-based indicator (Dibuz and Shelton 1967) and/or the detection reagent DACA (Paulitsch 1986) and the fractured surface ratio covered by wood fibers and adhesive, respectively, then is estimated by applying an image processing procedure.

\subsection{Material}

\subsubsection{Preliminary test series}

The test bars with cross-sections of $t \times b=40 \times 50 \mathrm{~mm}^{2}$ were made from Norway spruce (Picea abies Karst.) solid timber. While the tests with the established device could be carried out directly on the bars, the specimens tested with the new device had to be trimmed first. Block shear test specimens with dimensions $40 \times 50 \times 50 \mathrm{~mm}^{3}$ were cut from the bars, assuring that the acting shear force would be placed exactly in the area of $t \times b=40 \times 50 \mathrm{~mm}^{2}$ to be tested. Because the thickness of the specimens was smaller than $50 \mathrm{~mm}$, derived shear strengths had to be corrected with $k=0.956$ according to (1).

Prior to testing specimens were stored under climate conditions at $20^{\circ} \mathrm{C}$ and $65 \%$ relative humidity until equilibrium moisture content was reached. After the tests spot checks of the moisture content were made using the oven-dry method according to ISO standard 3130 (ISO 1975) and the ovendry density was calculated for each specimen. The mean moisture content was $11.3 \%$ with a variation of $10.4 \%$ to $12.2 \%$. The density of the specimens is listed in Table 1 .

\subsubsection{Main test series}

The test bars with a cross-section of $50 \times 50 \mathrm{~mm}^{2}$ were taken from homogenous $(h)$ and combined $(c)$ glued-laminated timber of strength class GL 24 (CEN 2005), which was produced from Norway spruce lamellas (Picea abies Karst.) bonded with different types of adhesives (Table 2).

Again the test series with the established device were carried out on bars whilst specimens to be tested with the new device had to be shaped accordingly. The thickness in the grain direction of the sheared area was exactly $50 \mathrm{~mm}$. Therefore no correction of the shear strength values was necessary.

Before carrying out the shear tests, the test bars were stored in a climatic chamber at $20^{\circ} \mathrm{C}$ and $65 \%$ relative humidity. After the shear tests the moisture content of the specimens was derived according to ISO standard 3130 (ISO
1975). A mean value of $11.5 \%$ (variation between $9.8 \%$ and $12.5 \%$ ) was found for the specimens tested with the established shear test device. The respective values for the specimens tested with the new device were $12.3 \%$ (mean value) and $11.3 \%$ to $13.3 \%$ (variation). The impact of the small moisture content difference (about $0.8 \%$ ) on the shear strength, which may result in a maximum change of $2 \%$, was neglected.

\section{Results and discussion}

\subsection{Preliminary test series}

The results of the preliminary test series which aimed at quantifying the influence of friction conditions at the support of the test bars are depicted in separate normal probability plots for the high-density samples (Fig. 8a) and the low-density samples (Fig. 8b). All relevant statistical parameters are indicated in the plots.

It can be seen that for both the high-density sample and the low-density sample the shear strength of the specimens tested with an interlaying sheet of Teflon ${ }^{\circledR}$ between steel plate and test bar is far below the respective values of the other testing situations. A statistical test to prove significance in difference is not needed. For double-sided Norway spruce (Picea abies Karst.) test specimens subjected to compressive block shear, a mean shear strength of $f_{v, a}=2.2 \mathrm{~N} / \mathrm{mm}^{2}$ in case of frictionless support conditions has been reported by Henrici and Scheicher (1988), compared to $f_{v, a}=4.9 \mathrm{~N} / \mathrm{mm}^{2}$ when the specimens were tested on rough support.

Carrying out a $t$-test when comparing the series "indented steel plate" and "plain steel plate" it can be found that the difference in mean values for the low-density sample is significant on the $5 \%$ level $(P$-value $=0.02)$, whereas significance in difference of mean values for the high-density sample is not given $\left(P_{05}=0.40\right)$. Except the test series "indented steel plate" and "plain steel plate" of the high-density sample, similar coefficients of variation $(\mathrm{CoV})$ of on average $3.9 \%$ were found.

All test specimens tended to lift off from the support as can be seen in Fig. 9. This phenomenon occurred pronounced for specimens tested with the Teflon ${ }^{\circledR}$ interlayer sheet and with the plain steel plate. The testing situation with indented steel plate as well showed tendencies of lift off caused by local compression deformations parallel to the grain near the sheared area. The increasing lift off during testing being accompanied with an increasing reduction of the supporting surface leads to continuously raising stresses parallel to the grain which itself further increases the local deformations together with lift off. Since compression strength parallel to the grain strongly depends on density, a 
Fig. 8 Normal probability plot of shear strength $f_{v, a}$ depending on frictional properties of the support of the test bar (indented steel plate, plain steel plate, Teflon ${ }^{\circledR}$ sheet between test bar and plain steel plate) for the high-density sample (a) and for the low-density sample (b)

Abb. 8 Darstellung der

Schubfestigkeitswerte $f_{v, a}$ in

Abhängigkeit der

Auflagerbedingungen der

Prüfstange (Stahlplatte mit

Zahnung, glatte Stahlplatte,

Teflon ${ }^{\circledR}$-Schicht zwischen

Prüfstange und glatter

Stahlplatte) für die Stichprobe

hoher Dichte (a) und geringerer

Dichte (b) in einem

Wahrscheinlichkeitsnetz mit normalverteilter Ordinate

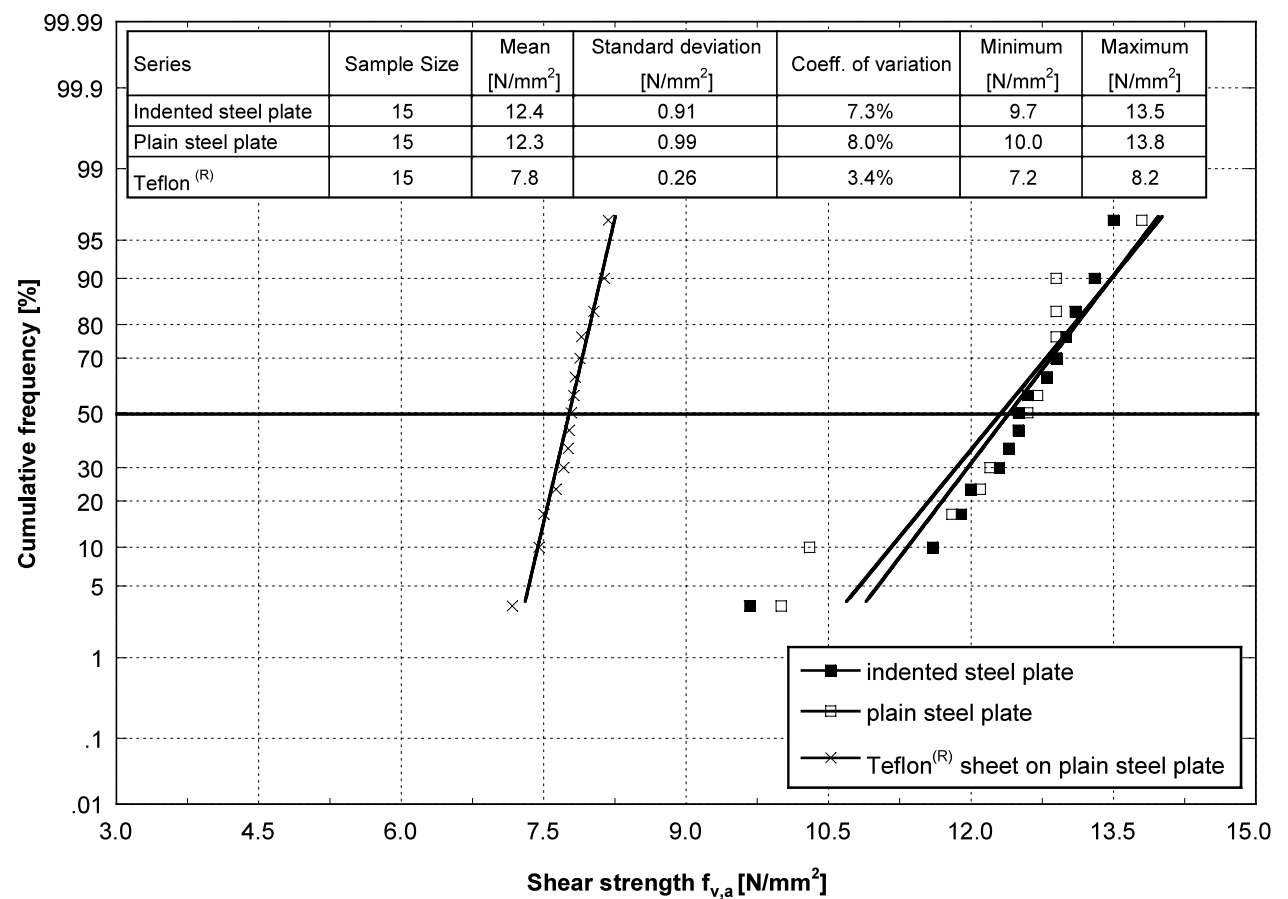

(a)

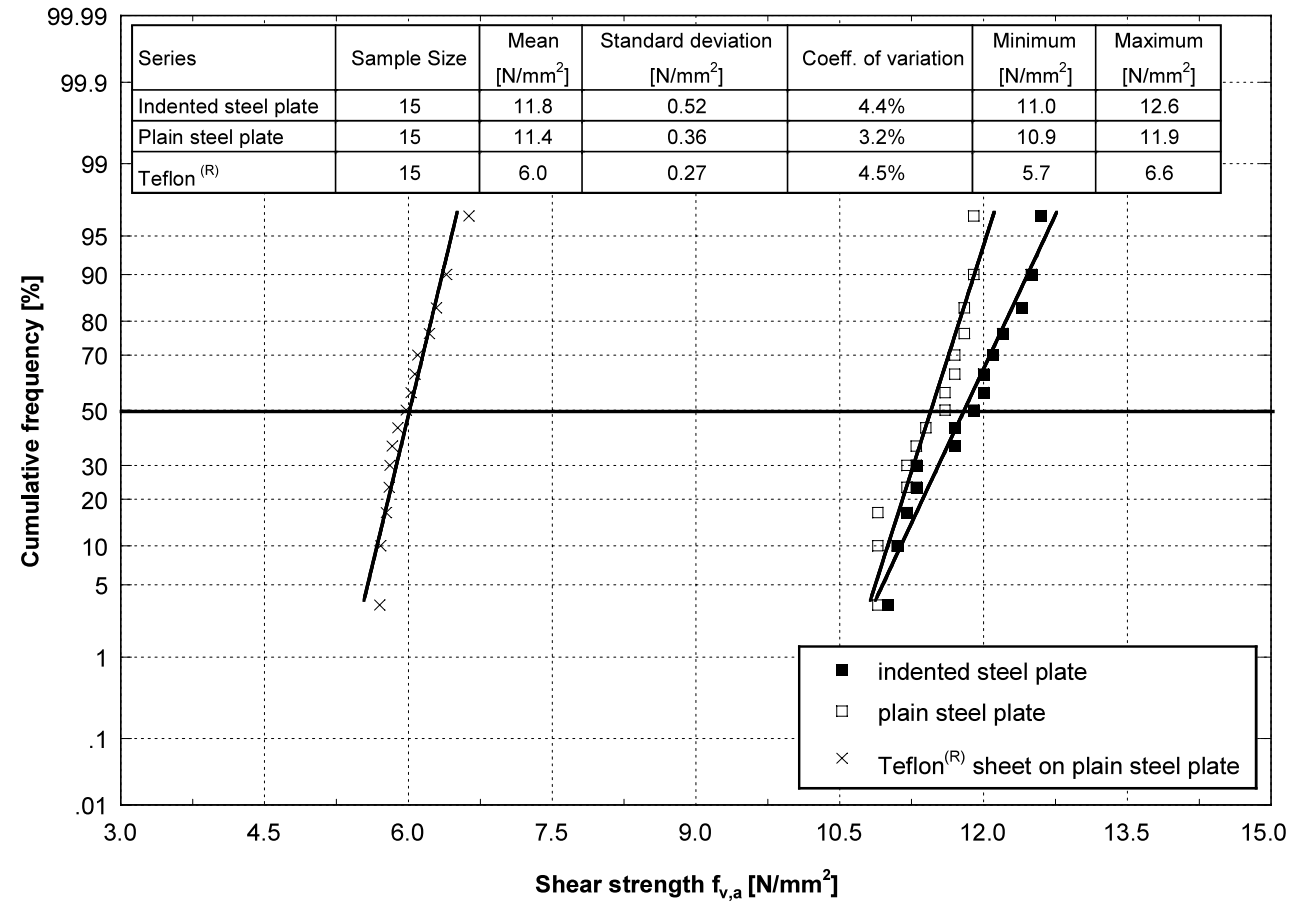

(b) reduction in supporting area could mainly be observed with the low-density sample.

In the end, the reduction in supporting surface during the test results in a continuous change of the inclination of the resultant (net force) $R$ (Fig. 2) which means that simultaneously acting stresses parallel and perpendicular to the sheared area occur and thus derived shear strengths are not pure ones. Hence theoretical considerations developed in the introduction part of the paper could be confirmed by the tests.

\subsection{Main test series}

\subsubsection{Comparison of established and new test equipment}

Mean values, 10-percentiles and 90-percentiles of shear strengths and percentages of wood failure are shown in 


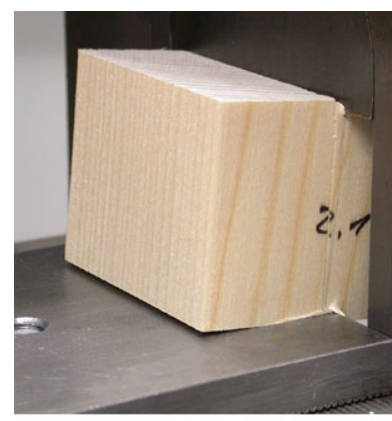

(a)

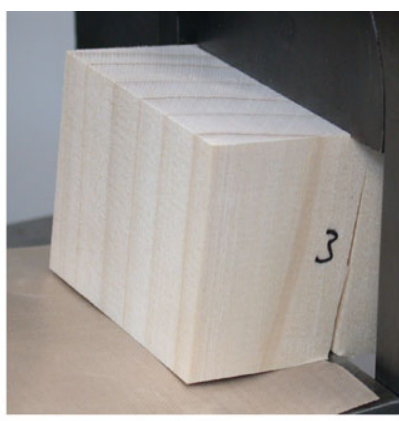

(b)

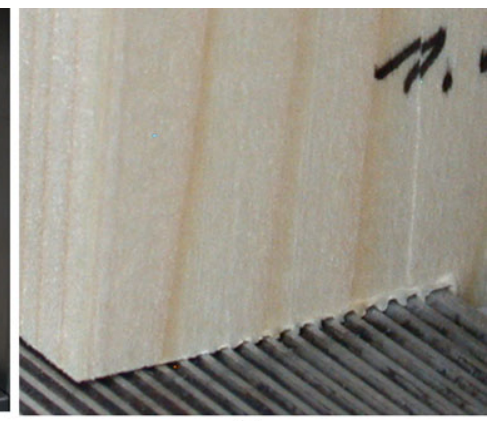

(c)

Fig. 9 Independently from the friction conditions at the support, block shear specimens show tendency of lift off from support (a-c) when tested with the established shear test device. The indented steel plate (c) leads to local deformations of the specimens near the sheared area

Abb. 9 Unabhängig von den Reibungsverhältnissen in der Auflagerzone tendieren die Prüfkörper bei der herkömmlichen Prüfeinrichtung zum Abheben (a-c). Die Stahlplatte mit Zahnung (c) bewirkt nahe der Scherfläche lokale Eindrückungen in den Prüfkörpern

Figs. 10a and 10b, respectively. Lower and upper percentiles were taken directly from ranked test results without any interpolation or distribution fitting but rather by assigning that single test value to the 10/90-percentile which was directly below/above the respective percentile. From Fig. 10a it can be concluded, that independent of the type of adhesive shear strengths derived with the new test device as well as their variability are lower than those resulting from tests with the established device. The differences exhibit the same trend on the mean level and on levels of 10 and 90 percent, which at the first glance would mean that the differences are not affected by strength of material or adhesive bond, respectively. When correlating all pairs of shear strength values derived with both test devices (Fig. 11) the test data exhibit a linear trend but the coefficient of determination is low. The dependency of shear strengths derived with both test devices is influenced by the level of strength: At high levels of bondline strength, testing with the new device leads to lower values compared to tests performed with the established device. The reason for this phenomenon was identified by a detailed examination of the specimens. As a result of limited area of load transfer, specimens with high bondline strength tend to crush due to exceeding compression stresses parallel to the grain.

Regarding percentages of wood failure (Fig. 10b), no clear difference between established and new test tool can be seen. In the present study, wood failure percentages for PUR-type adhesives were generally very high and exhibited a small variation. On the other hand, some very low percentages of wood failure, especially for MUF-type adhesives occurred.

\subsubsection{Benchmarking of test results to limits required by standard EN 386}

Benchmarking of test results to the limits required by bondline quality control in standard EN 386 (CEN 2001) is vi- sualized in Fig. 12. Whereas the requirements for the mean values of shear strength and percentages of wood failure are met by all producers in case of shear tests performed with the established device, the respective values of specimens provided by producers $\mathrm{A}$ and $\mathrm{H}$ do not reach the target limit anymore when tested with the new device (Fig. 12).

Hence, the type of test equipment used for the block shear tests affects the test results in terms of shear strength and percentage of wood failure. That is why the limits given by quality control standards (e.g. EN 386) cannot be directly applied to the new shear test device. They need further verification and development. Additionally, it has to be clearly said that the limits given in standard EN 386 are only valid for that type of shear testing device they were derived with. In that sense, standard EN 386 and EN 392 are lacking of precision in describing the properties of this shear test device. Furthermore, in order to be able to reliably assess and compare percentages of wood failure the bondlines should be analysed using a computerised method as e.g. suggested in Künniger (2008).

\subsubsection{Handling of the new test device}

The test series with the new test device could be carried out without any noticeable complication compared to the established procedure. When using templates, cutting of single block shear specimens from the test bars to be tested with the new device can easily be done. Request on geometrical precision of trimming the single block shear specimens however is higher, especially regarding the correct position of the bondline with respect to the sheared area within the new test device (Fig. 5). Due to limited travel of piston of the new test device some specimens could not be sheared completely until failure occurred. This shortcoming has to be overcome by a further development of the test device, since manually splitting the bondlines perpendicular to the grain 
Fig. 10 Mean values, 10-percentiles and 90-percentiles of shear strength (a) and percentage of wood failure (b) derived with either the established shear testing device or the new one. Test data is grouped by type of adhesive (MUF, PUR, RF/UF/EPI)

Abb. 10 Mittelwerte,

10-Prozent- und

90-Prozent-Quantilen der Scherfestigkeit (a) und des Faserbruchanteils (b) ermittelt mit der herkömmlichen und mit der neuen Prüfeinrichtung. Die Versuchsdaten sind nach Klebstofftyp (MUF, PUR, $R F / U F / E P I)$ gruppiert

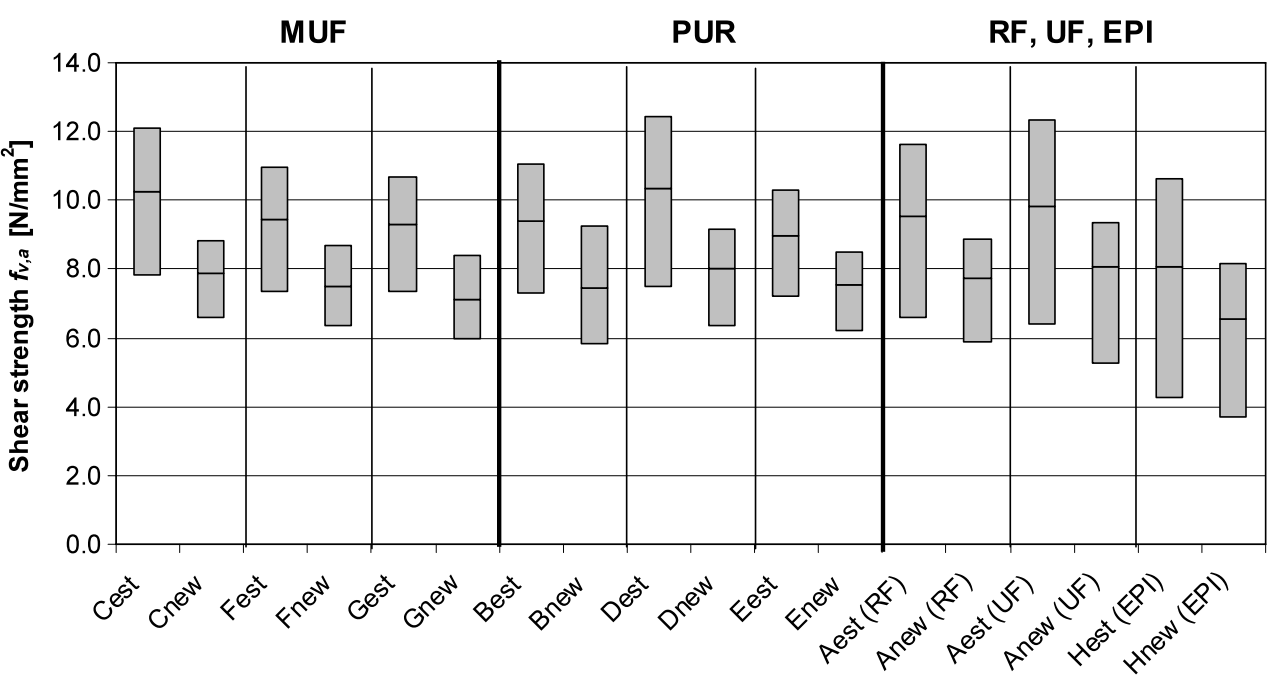

Glulam plants, grouped acc. to type of adhesive used in glulam production

(a)

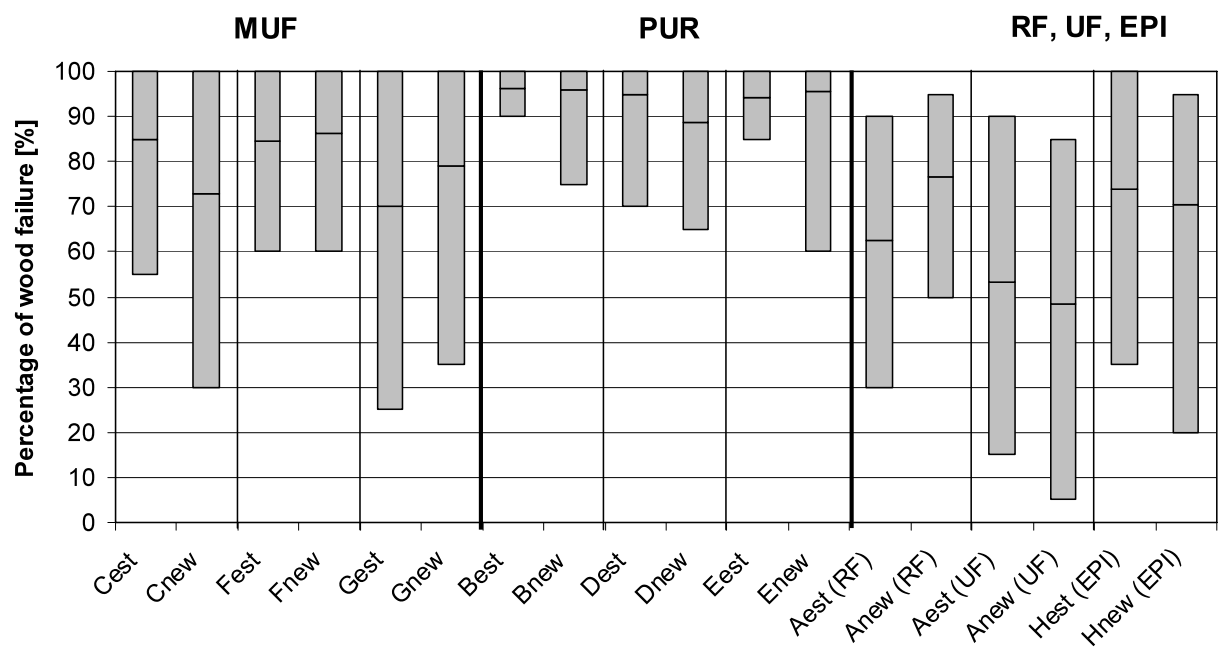

Glulam plants, grouped acc. to type of adhesive used in glulam production

(b) after the test can provoke misinterpretation of percentages of wood failure. One main advantage of the new test device lies in the fact that the test results may not be influenced by the person who carries out the test, since the test specimen is not to be taken hold of during the shear test.

\section{Conclusion}

From the test results of the preliminary series on the influence of friction conditions at the support of the test bars it can be concluded, that

- the resulting stresses in the bond line depend on the actual design of the shear testing device and on the properties of the supports with regard to friction;
- in the course of the shear test, the supporting surface of the specimens is reduced continuously due to occurring compression deformations near the sheared area as well as due to lift off of the specimen. The resulting inclination of the net force in the sheared area thereby depends on the density of the specimen and on the load level;

- inclined resultants being not in line with the sheared area lead to wrong test results since measured shear stress is accompanied by noticeable stresses perpendicular to the sheared area;

- in standards for the quality control of bondlines specifications for test devices to perform block shear tests should be put in more precise terms.

The main series comparing the established shear test device with the alternative one led to the following conclusions: 
Fig. 11 Correlation of shear strengths derived with established and with the new test equipment

Abb. 11 Korrelation der Scherfestigkeiten ermittelt mit der herkömmlichen und mit der neuen Prüfeinrichtung
Fig. 12 Shear strength with regard to percentage of wood failure derived with new and established shearing test device compared to requests of EN 386 (CEN 2001): Mean values Abb. 12 Scherfestigkeit in Abhängigkeit des Faserbruchanteils ermittelt mit der herkömmlichen und mit der neuen Prüfeinrichtung gemessen an den Anforderungen der EN 386 (CEN 2001): Mittelwerte
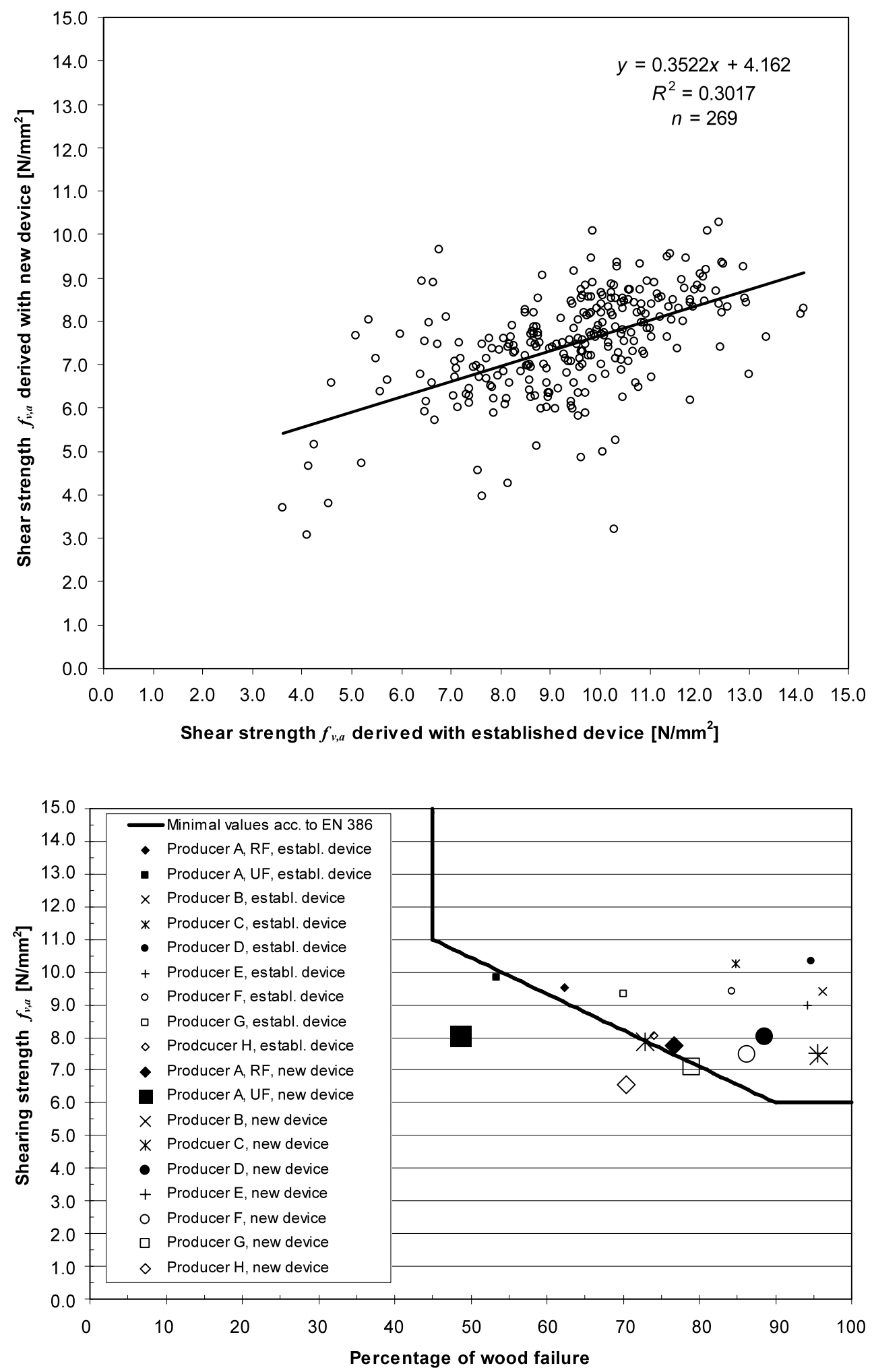

- Instead of shear tests according to common standards used in the quality control of bondlines, axial compression tests with an oblique angle between the grain and the loading direction of $14^{\circ}$ (slope $1: 4$ ) can be made.
- The prototype of an according new shearing tool has the potential of deriving reproducible shear strength values not being influenced by the person who carries out the tests since along the shear test the specimen is not taken 
hold of, this being an advantage in glulam quality control where reproducible and objective test results are of big importance.

- Shear strengths of bondlines exhibit lower variation when the tests are carried out with the new shearing tool, whereas with regard to percentages of wood failure no differences were found.

- The validity of target limits of shear strength and percentages of wood failure in glulam quality control standards has to be questioned. Actual limits seem to be related to certain types of shearing tools. Hence as already stated above, construction details of these tools have to be prescribed more precisely in the respective standards. For the new test device respective limits for shear strength and percentage of wood failure have yet to be developed. In the course of quality control of glulam the main focus has to be targeted to shear strength, the latter directly influencing the mechanical properties of the glued-laminated timber. Percentages of wood failure are of lower interest. However, when investigating and further developing adhesives, percentages of wood failure gain of importance since they help to improve adhesive products and application technique.

Acknowledgements The study was financially supported by the Swiss Federal Office for the Environment FOEN (Fonds zur Förderung der Wald- und Holzforschung, project number 2007.04). The prototype of the new shear test device was designed by Prof. em. E. Gehri and produced by Zum Wald Maschinen- und Apparatebau, CH-3762 Erlenbach, Switzerland (www.zum-wald.ch). Eight members of the Swiss Glulam Association SFH (www.glulam.ch) supplied the test material. The assistance of the Empa technicians W. Risi, D. Heer and M. Straessle taking care of sampling and data analysis, preparation of specimens and performing shear tests, respectively, is gratefully acknowledged.

\section{References}

Abplanalp B, Bogusch W (2007) Die Baustoffqualität als Basis für die Sicherheit von Holztragwerken. Schweiz Holzbau 73(1):52-57

AITC Standard 190.1 (2002) American national standard-structural glued laminated timber. American Institute of Timber Construction AITC, Centennial, Colorado, USA

AITC Standard 200 (2004) Inspection manual for structural glued laminated timber. American Institute of Timber Construction AITC, Centennial, Colorado, USA

Arcan M, Hashin Z, Voloshin A (1978) Method to produce uniform plane-stress states with applications to fiber-reinforced materials. Exp Mech 18(4):141-146

ASTM Standard D 143-94 (2000) Standard test methods for small clear specimens of timber. American Society for Testing and Materials ASTM International, West Conshohocken, Pennsylvania, USA

ASTM Standard D 905-03 (2003) Standard test method for strength properties of adhesive bonds in shear by compression loading. American Society for Testing and Materials ASTM International, West Conshohocken, Pennsylvania, USA

Baumann R (1922) Die bisherigen Ergebnisse der Holzprüfungen in der Materialprüfungsanstalt an der Technischen Hochschule Stuttgart, Germany
Bodig J, Jayne BA (1993) Mechanics of wood and wood composites. Krieger Publishing Company, Malabar

Coker EG, Coleman GP (1935) Photo-elastic investigations of sheartests of timber. Institution of Civil Engineers, London

Dibuz JJ, Shelton FJ (1967) Glueline identification. For Prod J 17(10):20-22

EN 386 (2001) Glued laminated timber-performance requirements and minimum production requirements. Comité Européen de Normalisation CEN, Brussels, Belgium

EN 392 (1995) Glued laminated timber-shear test of glue lines. Comité Européen de Normalisation CEN, Brussels, Belgium

EN 408 (2003) Timber structures-structural timber and glued laminated timber-determination of some physical and mechanical properties. Comité Européen de Normalisation CEN, Brussels, Belgium

EN 14080 (2005) Timber structures-glued laminated timberrequirements. Comité Européen de Normalisation CEN, Brussels, Belgium

Feldborg T (1991) Determination of some mechanical properties of timber in structural sizes. In: Proceedings of the 1991 international timber engineering conference, 2-5 September 1991, London, UK

Gehri E, Steurer T (1979) Holzfestigkeit bei Beanspruchung schräg zur Faser. SAH Bull 7(2):1-27. Schweizerische Arbeitsgemeinschaft für Holzforschung SAH, Zurich, Switzerland

Hankinson RL (1921) Investigation of crushing strength of spruce at varying angles of grain. US Air Service Information Circular Vol 3 (Circular No 259)

Henrici D, Scheicher U (1988) Shear strength of glued lap joints in test specimens with frictionless support. Holz Roh- Werkst 46(1):33

Hörig H (1931) Zur Elastizität des Fichtenholzes. Z Tech Phys 12(8):369-379

ISO Standard 3130 (1975) Wood-determination of moisture content for physical and mechanical tests. International Organization for Standardization ISO, Geneva, Switzerland

ISO Standard 6238 (2001) Adhesives-wood-to-wood adhesive bonds-determination of shear strength by compressive loading. International Organization for Standardization ISO, Geneva, Switzerland

ISO Draft Standard 12579.2 (2006) Timber structures-glued laminated timber-method of test for shear strength of glue lines. International Organization for Standardization ISO, Geneva, Switzerland

ISO Draft Standard 12578.2 (2007) Timber structures-glued laminated timber-component performance and production requirements. International Organization for Standardization ISO, Geneva, Switzerland

Jenkin CF (1920) Report on materials of construction used in aircraft and aircraft engines. University of Oxford, UK

Karlsen GG, Goodman WL (1967) Wooden structures. Mir, Moscow

Keylwerth R (1951) Die anisotrope Elastizität des Holzes und der Lagenhölzer. VDI-Forschungsheft, vol 430. Deutscher IngenieurVerlag, Düsseldorf

Kollmann F (1934) Die Abhängigkeit der Festigkeit und der Dehnungszahl der Hölzer vom Faserverlauf. Bauingenieur 15(19/20):198-200

Kollmann F, Côté WA Jr (1968) Principles of wood science and technology. Springer, Berlin

Kraemer O (1929) Untersuchungen über den Einfluß von Aufbau und Faserverlauf auf Zugfestigkeit, Biegung und Dehnung an Birkenfurnieren und Birkensperrholz. Deutsche Versuchsanstalt für Luftfahrt, Berlin

Künniger T (2008) A semi-automatic method to determine the wood failure percentage on shear test specimens. Holz Roh- Werkst 66(3):229-232 
Larsen HJ (1987) Determination of shear strength and strength perpendicular to grain. In: Proceedings of CIB-W18 meeting twenty, Paper 20-6-3, September 1987, Dublin, Ireland

Okkonen EA, River BH (1989) Factors affecting the strength of blockshear specimens. For Prod J 39(1):43-50

Paulitsch M (1986) Methoden der Spanplattenuntersuchung. Springer, Berlin

Radcliffe BM, Suddarth SK (1955) The notched beam shear test for wood. For Prod J 5(2):131-135

Stüssi F (1945) Zum Einfluss der Faserrichtung auf die Festigkeit und den Elastizitätsmodul von Holz. Schweiz Bauztg 126(22):247248
Stüssi F (1946) Holzfestigkeit bei Beanspruchung schräg zur Faser. Schweiz Bauztg 128(20):251-252

Stüssi F (1949) Holzfestigkeit schräg zur Faser. Schweiz Bauztg 67(6):90

Ylinen A (1963) A comparative study of different types of shear test of wood. Report FAO/WTC/63/MPT/5, The State Institute for Technical Research, Helsinki, Finland and Fifth Conference on Wood Technology, US Forest Products Laboratory, Madison, Wisconsin, USA

Yoshihara H, Matsumoto A (2005) Measurement of the shearing properties of wood by in-plane shear test using a thin specimen. Wood Sci Technol 39(2):141-153 